\title{
Anti- $N$-methyl-D-aspartate receptor (anti-NMDAR) encephalitis presenting to the emergency department with status epilepticus
}

\author{
Brodie Nolan, $\mathrm{MD}^{*}$; Katharina Plenk, $\mathrm{MD}^{\dagger}$; David Carr, $\mathrm{MD}^{\ddagger}$
}

\section{ABSTRACT}

Anti- $N$-methyl-D-aspartate receptor (anti-NMDAR) encephalitis is a recently described and underdiagnosed entity that typically affects young, previously healthy individuals. Patients usually present in phases, which may include refractory seizures, psychosis, unresponsiveness, and autonomic instability. The diagnosis of anti-NMDAR encephalitis is challenging; however, prompt diagnosis and early treatment can lead to complete recovery. The incidence of antiNMDAR encephalitis may be as high as four times that of encephalitis from herpes simplex, varicella-zoster, and West Nile viruses; however, it remains an underrecognized disorder. Early initiation of immunotherapy in anti-NMDAR encephalitis has been found to improve patient outcomes. Because of this, emergency physicians must be vigilant and consider this diagnosis in patients with altered mental status in whom a toxicologic or other etiology is not suspected. Early consideration of this diagnosis can facilitate urgent neurology consultation and prevent diagnostic delays arising from psychiatric referrals. It is essential to consider this diagnosis in suspicious emergency department presentations, particularly young patients who present with altered mental status, psychosis, or new-onset seizure activity when other obvious causes are ruled out. Emergency physicians should discuss the possibility of empirical intravenous immunoglobulin administration with neurology consultants if anti-NMDAR encephalitis is suspected. We describe the case of a 20-year-old man with antiNMDAR encephalitis who presented to the emergency department with status epilepticus.

\section{RÉSUMÉ}

L'encéphalite à anticorps antirécepteur du N-méthyl-Daspartate (NMDA) est un état pathologique décrit depuis peu et sous-diagnostiqué, qui frappe généralement les jeunes en bonne santé. Souvent, les patients consultent à différentes phases de la maladie, qui peuvent comprendre des crises épileptiques réfractaires, la psychose, l'absence de réactivité ou l'instabilité du système nerveux autonome. Le diagnostic d'encéphalite à anticorps antirécepteur du NMDA n'est pas facile à poser, mais un diagnostic rapide et un traitement précoce peuvent conduire au rétablissement complet. La fréquence de l'encéphalite à anticorps antirécepteur du NMDA peut être de quatre fois supérieure à celle de l'encéphalite causée par les virus de l'herpès simplex, de la varicelle et du zona et du Nil occidental; pourtant, il s'agit d'une affection mal reconnue. Des études ont démontré que l'amorce précoce de l'immunothérapie dans l'encéphalite à anticorps antirécepteur du NMDA permettait d'améliorer les résultats cliniques; c'est pourquoi les urgentologues doivent faire preuve de vigilance et envisager ce diagnostic chez les patients qui présentent une altération de l'état mental mais chez qui il n'y a pas de présomption de cause toxicologique ou d'autre nature. Le fait d'envisager rapidement ce diagnostic peut accélérer les consultations urgentes en neurologie et prévenir les retards dans la pose du diagnostic découlant de consultations en psychiatrie. II est essentiel d'envisager ce diagnostic dans les cas douteux au service des urgences, surtout chez les jeunes patients qui présentent une altération de l'état mental, qui sont en état de psychose ou qui souffrent de crises épileptiques d'installation récente, après exclusion d'autres causes possibles évidentes. Les urgentologues devraient discuter, avec les consultants en neurologie, de la possibilité d'administrer des immunoglobulines, par voie intraveineuse, de manière empirique, dans les cas présumés d'encéphalite à anticorps antirécepteur du NMDA. Sera décrit ici le cas d'un homme de 20 ans, atteint d'une encéphalite à anticorps antirécepteur du NMDA, se manifestant, au service des urgences, sous forme d'état de mal épileptique.

Keywords: autoimmune, encephalitis, N-methyl-D-aspartate receptor

From the *Department of Medicine, University of Toronto, Toronto, ON; †Department of Internal Medicine, York Central Hospital, Richmond Hill, ON; and $\ddagger$ Department of Family and Community Medicine, University of Toronto, University Health Network, Toronto, ON.

Correspondence to: Dr. David Carr, Toronto General Hospital, R. Fraser Elliott Building, Ground -480, 200 Elizabeth Street, Toronto, ON M5G 2C4; david.carr@uhn.on.ca.

This article has been peer reviewed. 
Autoimmune encephalopathies are a group of conditions that arise from autoantibodies that target synaptic proteins. They frequently cause encephalitis and, if recognized early, are treatable. Anti- $\mathrm{N}$-methyl-Daspartate receptor (anti-NMDAR) encephalitis is a new entity within this spectrum of disorders and was first described in 2005 by Dalmau and colleagues. ${ }^{1}$ Anti-NMDAR encephalitis was initially thought to be a paraneoplastic syndrome due to its association with limbic encephalitis in four young women with ovarian teratomas. Two years after this initial description, the pathology of autoantibodies targeting the NR1 subunit of the NMDAR was elucidated. ${ }^{1}$ Subsequent research suggests that these autoantibodies can also decrease the number of NMDARs in target cells by inducing crosslinking and internalization of the receptors through autophagy. ${ }^{2}$

Anti-NMDAR encephalitis most commonly presents in young women of reproductive age (with a female to male ratio of $4: 1),{ }^{3}$ although it has been reported in both males and females ranging in age from 2 to 84 years. $^{4}$ A retrospective study of patients presenting with a diagnosis of "encephalitis" found serologic evidence supporting the presence of antiNMDAR antibodies in $20 \%$ of cases. ${ }^{5}$ The incidence of anti-NMDAR encephalitis may be as high as four times that of encephalitis from herpes simplex, varicella-zoster, and West Nile viruses. ${ }^{6,7} \mathrm{~A}$ recent review identified over 400 patients with this disorder over a 3 -year period, illustrating that it is not rare but is often misdiagnosed as a seizure disorder or psychiatric illness. ${ }^{8}$ Anti-NMDAR encephalitis remains an underrecognized disorder but should be included in the differential diagnosis of patients with acute psychiatric symptoms and neurologic deterioration.

We describe the case of a 20-year-old man with antiNMDAR encephalitis who presented to the emergency department (ED) with status epilepticus.

\section{CASE REPORT}

A 20-year-old man presented to the ED with multiple episodes of generalized shaking and facial twitching lasting 30 to 60 seconds. He was otherwise healthy and on no medications. He was seen a week previously at another community ED for a syncopal episode and questionable seizure activity. On that visit, he had an unremarkable computed tomographic (CT) head scan and was discharged with outpatient neurology follow-up.
On arrival at the ED, he was drowsy with a Glasgow Coma Scale (GCS) score of 13 (eye opening 3, verbal 4, motor 6). His vital signs were as follows: pulse rate of 94 beats per minute; blood pressure of 146/81 mm $\mathrm{Hg}$; respiratory rate of 18 breaths per minute; temperature of $36.9^{\circ} \mathrm{C}\left(98.4^{\circ} \mathrm{F}\right)$; and oxygen saturation of $99 \%$ on room air. His blood sugar was $5.8 \mathrm{mmol} / \mathrm{L}$, and he appeared well nourished and healthy. The patient answered simple questions but was unable to carry on a meaningful conversation. His speech was normal in rate and rhythm, and there was no expressive or receptive aphasia. He had a normal cranial nerve examination with equal and reactive pupils of $3 \mathrm{~mm}$. He had normal strength and sensation in all limbs and no evidence of neglect. Deep tendon reflexes were normal, and he had down-going plantar responses bilaterally. Cerebellar testing was normal. His gait was not assessed due to his depressed level of consciousness, and the remainder of the physical examination was unremarkable.

Initial laboratory investigations, including complete blood count, electrolytes, urea, creatinine, thyroidstimulating hormone, and urinalysis, were all within normal limits. A urine toxicology screen was negative for amphetamines, barbiturates, benzodiazepines, cocaine, opiates, and cannabis. Serum ethanol, acetaminophen, and salicylate were undetectable. Because of his recent normal CT head scan, CT was not repeated. A lumbar puncture was performed, which revealed a white blood cell count of $7.0 \times 10^{6} / \mathrm{L}$ (normal $<3.0 \times 10^{6} / \mathrm{L}$ ), a red blood cell count of $2.0 \times 10^{6} / \mathrm{L}$ (normal 0 ), glucose of $3.2 \mathrm{mmol} / \mathrm{L}$ (normal $>3.0 \mathrm{mmol} / \mathrm{L}$ ), and protein of $0.18 \mathrm{~g} / \mathrm{L}$ (normal $<0.45 \mathrm{~g} / \mathrm{L}$ ). The cerebrospinal fluid (CSF) was negative for cryptococcal antigen, and viral polymerase chain reaction testing was negative for herpes simplex types 1 and 2, varicella-zoster virus, cytomegalovirus, and Epstein-Barr virus. Subsequent CSF testing for oligoclonal bands was positive.

In the $\mathrm{ED}$, the patient continued to have intermittent episodes of facial twitching and was given $2 \mathrm{mg}$ of lorazepam intravenously. There was no generalized seizure activity. His facial twitching stopped following the lorazepam administration; however, he remained drowsy and confused. He was referred to the internal medicine service, but prior to that assessment, he began having recurrent generalized seizure activity every 15 minutes, consistent with status epilepticus. This was refractory to intravenous administration of an 
additional lorazepam $2 \mathrm{mg}$, phenytoin $1 \mathrm{~g}$, and levetiracetam $500 \mathrm{mg}$. He was subsequently intubated and transferred to the intensive care unit (ICU) on a propofol infusion at a rate of $3 \mathrm{mg} / \mathrm{kg} / \mathrm{hr}$. On ICU arrival, the patient was started on carbamazepine $200 \mathrm{mg}$ orally 4 times a day via a nasogastric tube. An electroencephalogram (EEG) demonstrated multiple subclinical seizures in the left hemisphere with secondary generalization.

Brain magnetic resonance imaging (MRI) and magnetic resonance angiography $\left(T_{1}, T_{2}\right.$, fluid-attenuated inversion recovery [FLAIR], gradient echo, and diffusion sequences) performed the day after hospital admission was normal. After 48 hours, the patient was extubated, and continuous EEG monitoring showed no further seizure activity; however, he remained in a catatonic state and was both nonverbal and inattentive. After 3 days, he began to display brief visual tracking and exhibit choreiform type movements in his right arm and orofacial dyskinesias. This was initially thought to be secondary to pseudoseizures, and he was referred to Psychiatry. Ten days after hospital admission, serologic testing for NMDA receptor antibodies was performed and treatment was commenced with intravenous immunoglobulin (IVIG) $0.4 \mathrm{mg} / \mathrm{kg}$ daily for 5 days and methylprednisolone $1 \mathrm{~g}$ IV for 5 days for suspected antiNMDAR encephalitis. Twenty days after hospital admission, the patient's serum samples were reported positive for antibodies to NMDA (type 1/MR1) receptors, confirming the diagnosis of anti-NMDAR encephalitis. CT of the chest, abdomen, and pelvis revealed no malignancy or abnormalities, and a testicular sonogram was normal. Despite treatment, he continued to have profound difficulty with speech and swallowing and abnormal posturing of his limbs with orofacial dyskinesias. He was discharged home with outpatient cognitive rehabilitation after a 1-month hospital admission and has since regained independence with his activities of daily living and most of his instrumental activities of daily living.

\section{DISCUSSION}

Current understanding of anti-NMDAR encephalitis suggests that four clinically distinct phases of this condition exist: a prodromal phase, a psychotic/seizure phase, an unresponsive phase, and a hyperkinetic phase. ${ }^{3}$ These phases may vary in presentation, sequence, and severity. Typically, patients initially present with headache and fever and are often misdiagnosed as having an upper respiratory tract infection. This is followed by concentration difficulties and altered mental status or behavioural changes that often prompt a psychiatry referral, such as hallucinations, delusions, or paranoia., ${ }^{4,9}$, Subsequently, patients develop seizure activity, which is often tonic-clonic in nature and can require multiple medications for treatment. ${ }^{3,4}$ This can progress to a catatonic state and autonomic instability.,10

The diagnosis of anti-NMDAR encephalitis is challenging. MRI is unremarkable in some $50 \%$ of cases, with abnormal studies showing nonspecific $T_{2}$ FLAIR hyperintensity. ${ }^{1}$ EEGs may appear abnormal, with nonspecific slow, disorganized activity with or without interspersed seizure patterns. ${ }^{10} \mathrm{CSF}$ is usually abnormal initially, showing moderate lymphocytic pleocytosis, normal or mildly increased protein concentration, and CSF-specific oligoclonal bands. ${ }^{8,10} \mathrm{~A}$ recent indirect immunofluorescence technique and cell-based assay for detection of anti-NMDAR antibodies has great diagnostic promise but is not widely available. $^{3}$

All patients with suspected anti-NMDAR encephalitis should be worked up for the presence of a teratoma or other age- and gender-specific malignancy. No randomized controlled trials have evaluated treatment for anti-NMDAR encephalitis. A recent study suggests that immunotherapy, steroids, and IVIG in most cases and tumor removal when applicable result in substantial neurologic improvement in $81 \%$ of patients. ${ }^{11}$ Among patients who do not respond to initial immunotherapy, improved outcomes have been reported in those subsequently treated with rituximab, cyclophosphamide, or both. ${ }^{11}$ Another study, albeit small, found a mortality rate of $100 \%$ for patients who had delayed diagnosis and treatment initiation. $^{4}$

Early initiation of immunotherapy in anti-NMDAR encephalitis has been found to improve patient outcomes. ${ }^{11}$ Because of this, emergency physicians must be vigilant and consider this diagnosis in patients with altered mental status in whom a toxicologic or other etiology is not suspected. Early consideration of this diagnosis can facilitate urgent neurology consultation and prevent diagnostic delays arising from psychiatric referrals. Our patient was evaluated by two emergency physicians, an internist, a psychiatrist, an intensivist, and two neurologists before the diagnosis 
was considered. As a result, he had been admitted to hospital for 10 days before IVIG was commenced. IVIG is a relatively safe treatment and, as a result, can be started prior to serologic confirmation (as was done in the case we present). Early commencement of IVIG can lead to significantly improved outcomes in this devastating illness.

\section{CONCLUSION}

Anti-NMDAR encephalitis is a challenging diagnosis to make in the ED; however, its timely identification and treatment can be lifesaving. It is essential to consider this diagnosis in suspicious ED presentations, particularly young patients who present with altered mental status, psychosis, or new-onset seizure activity when other obvious causes are ruled out. Emergency physicians should discuss the possibility of empirical IVIG administration with neurology consultants if anti-NMDAR encephalitis is suspected.

Competing interests: None declared.

\section{REFERENCES}

1. Dalmau J, Tüzün E, Wu H-Y, et al. Paraneoplastic anti-Nmethyl-D-aspartate receptor encephalitis associated with ovarian teratoma. Ann Neurol 2007;61:25-36, doi:10.1002/ ana.21050.

2. Hughes EG, Peng X, Gleichman AJ, et al. Cellular and synaptic mechanisms of anti-NMDA receptor encephalitis. $\mathcal{7}$ Neurosci 2010;30:5866-75, doi:10.1523/JNEUROSCI.016710.2010 .
3. Peery HE, Day GS, Dunn S, et al. Anti-NMDA receptor encephalitis. The disorder, the diagnosis and the immunobiology. Autoimmun Rev 2012;11:863-72, doi:10.1016/j.autrev.2012. 03.001 .

4. Day GS, High SM, Cot B, Tang-Wai DF. Anti-NMDAreceptor encephalitis: case report and literature review of an under-recognized condition. 7 Gen Intern Med 2011;26:8116, doi:10.1007/s11606-011-1641-9.

5. Irani SR, Bera K, Waters P, et al. N-methyl-D-aspartate antibody encephalitis: temporal progression of clinical and paraclinical observations in a predominantly non-paraneoplastic disorder of both sexes. Brain 2010;133(Pt 6):1655-67, doi:10.1093/brain/awq113.

6. Gable MS, Gavali S, Radner A, et al. Anti-NMDA receptor encephalitis: report of ten cases and comparison with viral encephalitis. Eur 7 Clin Microbiol Infect Dis 2009;28:1421-9, doi:10.1007/s10096-009-0799-0.

7. Gable MS, Sheriff H, Dalmau J, et al. The frequency of autoimmune $\mathrm{N}$-methyl-D-aspartate receptor encephalitis surpasses that of individual viral etiologies in young individuals enrolled in the California Encephalitis Project. Clin Infect Dis 2012;54:899-904, doi:10.1093/cid/cir1038.

8. Dalmau J, Lancaster E, Martinez-Hernandez E, et al. Clinical experience and laboratory investigations in patients with anti-NMDAR encephalitis. Lancet Neurol 2011;10:6374, doi:10.1016/S1474-4422(10)70253-2.

9. Prüss H, Dalmau J, Harms L, et al. Retrospective analysis of NMDA receptor antibodies in encephalitis of unknown origin. Neurology 2010;75:1735-9, doi:10.1212/WNL.0b013 e3181fc2a06.

10. Dalmau J, Gleichman AJ, Hughes EG, et al. Anti-NMDAreceptor encephalitis: case series and analysis of the effects of antibodies. Lancet Neurol 2008;7:1091-8, doi:10.1016/S14744422(08)70224-2.

11. Titulaer MJ, McCracken L, Gabilondo I, et al. Treatment and prognostic factors for long-term outcome in patients with anti-NMDA receptor encephalitis: an observational cohort study. Lancet Neurol 2013;12:157-65, doi:10.1016/ S1474-4422(12)70310-1. 